\title{
Macrophage-Mediated Degradation of $\beta$-Amyloid via an Apolipoprotein E Isoform-Dependent Mechanism
}

\author{
Lingzhi Zhao, ${ }^{1 \star}$ Suizhen Lin, ${ }^{1 \star}$ Kelly R. Bales, ${ }^{1}$ Valentina Gelfanova, ${ }^{2}$ Deanna Koger, ${ }^{1}$ Cynthia DeLong, ${ }^{1}$ John Hale, ${ }^{2}$ \\ Feng Liu, ${ }^{1}$ Jesse M. Hunter, ${ }^{1}$ and Steven M. Paul ${ }^{1}$ \\ ${ }^{1}$ Neuroscience Discovery Research and ${ }^{2}$ Integrative Biology, Lilly Research Laboratories, Eli Lilly and Company, Indianapolis, Indiana 46285
}

\begin{abstract}
Recent studies suggest that bone marrow-derived macrophages can effectively reduce $\beta$-amyloid (A $\beta$ ) deposition in brain. To further elucidate the mechanisms by which macrophages degrade $\mathrm{A} \beta$, we cultured murine macrophages on top of $\mathrm{A} \beta$ plaque-bearing brain sections from transgenic mice expressing PDAPP [human amyloid precursor protein (APP) with the APP $\mathrm{Al7v}>\mathrm{F}_{\mathrm{F}}$ mutation driven by the platelet-derived growth factor promoter]. Using this ex vivo assay, we found that macrophages from wild-type mice very efficiently degrade both soluble and insoluble $\mathrm{A} \beta$ in a time-dependent manner and markedly eliminate thioflavine-S positive amyloid deposits. Because macrophages express and secrete apolipoprotein $\mathrm{E}(\mathrm{apoE})$, we compared the efficiency of $\mathrm{A} \beta$ degradation by macrophages prepared from apoE-deficient mice or mice expressing human apoE2, apoE3, or apoE4. Macrophages expressing apoE2 were more efficient at degrading $\mathrm{A} \beta$ than apoE3-expressing, apoE4-expressing, or apoE-deficient macrophages. Moreover, macrophage-induced degradation of $\mathrm{A} \beta$ was effectively blocked by an anti-apoE antibody and receptor-associated protein, an antagonist of the low-density lipoprotein (LDL) receptor family, suggesting involvement of LDL receptors. Measurement of matrix metalloproteinase-9 (MMP-9) activity in the media from human apoE-expressing macrophages cocultured with $\mathrm{A} \beta$-containing brain sections revealed greater levels of MMP-9 activity in apoE2-expressing than in either apoE3- or apoE4-expressing macrophages. Differences in MMP-9 activity appear to contribute to the isoform-specific differences in $\mathrm{A} \beta$ degradation by macrophages. These apoE isoform-dependent effects of macrophages on $\mathrm{A} \beta$ degradation suggest a novel "peripheral" mechanism for $\mathrm{A} \beta$ clearance from brain that may also, in part, explain the isoformdependent effects of apoE in determining the genetic risk for Alzheimer's disease.
\end{abstract}

\section{Introduction}

$\beta$-Amyloid $(\mathrm{A} \beta)$ accumulation and senile plaque formation in brain are striking neuropathological hallmarks of Alzheimer's disease $(\mathrm{AD})$. Excessive $\beta$-amyloid deposition may result from increased $\mathrm{A} \beta$ synthesis as occurs in familial early-onset $\mathrm{AD}$ and (or) decreased $\mathrm{A} \beta$ clearance in brain (Selkoe, 2001). There is, however, no compelling evidence that increased $A \beta$ production occurs in the more common late-onset forms of $\mathrm{AD}$, suggesting that insufficient or impaired $\mathrm{A} \beta$ clearance may drive $\mathrm{A} \beta$ deposition and amyloid plaque formation.

The $\varepsilon 4$ allele of the apolipoprotein $\mathrm{E}(A P O E)$ gene remains the most widely replicated genetic risk factor for late-onset $\mathrm{AD}$, with $\varepsilon 4$ carriers having a greater risk (3-15-fold), as well as an earlier age of disease onset (Saunders et al., 1993). In contrast, inheritance of the $\varepsilon 2$ allele appears to be protective (Corder et al., 1994). By characterizing human amyloid precursor protein (APP) with the $\mathrm{APP}_{717 \mathrm{~V}>\mathrm{F}}$ mutation driven by the platelet-derived growth factor promoter (PDAPP) transgenic mice expressing the three

Received Nov. 4, 2008; revised Jan. 25, 2009; accepted Feb. 9, 2009.

We thank Prof. Guojun Bu for the generous gift of RAP, Dr. Shaoyou Chu and Michail Esterman for assistance with confocal microscopy and image analysis, Dr. Ronald DeMattos and Dr. Xiyun Chai for manuscript discussion, and Jeff Hanson for assistance with Image-Pro Plus software.

*L.Z. and S.L. contributed equally to this work.

Correspondence should be addressed to Dr. Steven M. Paul, Lilly Research Laboratories, Eli Lilly and Company, Lilly Corporate Center, Indianapolis, IN 46285. E-mail: Paul_Steven_M@Lilly.com. DOI:10.1523/JNEUROSCI.5302-08.2009

Copyright $\odot 2009$ Society for Neuroscience $\quad$ 0270-6474/09/293603-10\$15.00/0 common human apoE isoforms, we have previously demonstrated an apoE isoform-specific effect on $\mathrm{A} \beta$ burden, independent of $\mathrm{A} \beta$ synthesis, indicating that the interactions between apoE and $\mathrm{A} \beta$ are critical for $\mathrm{A} \beta$-associated neuropathology (Holtzman et al., 1999; Fagan et al., 2002).

In brain, apoE is mainly synthesized and secreted by astrocytes and microglia (Boyles et al., 1985; Xu et al., 2006), both of which are found to surround amyloid plaques. Recently, we reported that astrocytes promote $\mathrm{A} \beta$ clearance via an apoE-dependent mechanism (Koistinaho et al., 2004). In contrast, the precise role of microglia on $\mathrm{AD}$ pathology is unknown. Activation of microglia does trigger $\mathrm{A} \beta$ phagocytosis, but it is unclear if microglia can effectively degrade internalized A $\beta$ (Paresce et al., 1996, 1997; Chung et al., 1999; Wegiel et al., 2001).

Macrophages are the peripheral counterpart of microglia and have attracted attention recently based on the findings that a subset of microglia surrounding and invading $A \beta$-containing plaques in transgenic AD mouse models are in fact bone marrow derived (Malm et al., 2005; Simard et al., 2006). Bone marrowderived microglia (BMDM), but not resident microglia, have been reported to prevent the formation and even eliminate brain amyloid deposits (Simard et al., 2006). Circulating BMDM that are recruited to brain may, therefore, play an important role in enhancing $\mathrm{A} \beta$ clearance.

Although macrophages have been shown to readily internalize $\mathrm{A} \beta$, less is known about their ability to effectively degrade various forms of $\mathrm{A} \beta$. To further elucidate the mechanisms of $\mathrm{A} \beta$ clear- 
ance by BMDM and to explore the possible cellular mechanisms associated with apoE isoform-dependent $\mathrm{A} \beta$ deposition and amyloid formation, we characterized the ability of peritoneal macrophages prepared from wild-type and human apoEtargeted replacement mice to degrade $A \beta$. In addition to internalizing $\mathrm{A} \beta$, we found that macrophages are extremely efficient at degrading soluble and insoluble $A \beta$, including amyloid itself. The ability of macrophages to degrade $\mathrm{A} \beta$ was facilitated by apoE expression, was also apoE isoform-dependent $(\mathrm{E} 2>\mathrm{E} 3>\mathrm{E} 4)$, and blocked by the low-density lipoprotein (LDL) receptor antagonist receptor-associated protein (RAP). Importantly, we found that the apoE isoform-dependent macrophage-mediated $\mathrm{A} \beta$ degradation was, in part, mediated by secretion of matrix metalloproteinase-9 (MMP-9). Our data suggest that macrophage-mediated $\mathrm{A} \beta$ degradation in brain may constitute a novel peripheral clearance mechanism and delineates a previously unknown role for apoE in modulating $\mathrm{A} \beta$-degrading proteases that may help explain the role of apoE as a genetic risk factor for AD.

\section{Materials and Methods}

Cell culture and reagents. Peritoneal macrophages from the following mouse models, C57BL/6 mice [wild type (WT)], Apoe-targeted deletion $\left(A p o e^{-1-}\right.$ ), and APOE-targeted replacement mice (apoE2, apoE3, or apoE4), were prepared as described previously (Sullivan et al., 1997; Davies and Gordon, 2005). Briefly, WT or mice of the indicated APOE genotypes, at 8-12 weeks of age, were injected intraperitoneally with 1.5 $\mathrm{ml}$ of aged $4 \%$ Brewer thioglycolate solution (Difco Laboratories). Four days after injection, macrophages were harvested by lavage with $10 \mathrm{ml}$ of growth medium [RPMI 1640 (containing $25 \mathrm{mM}$ HEPES buffer and L-glutamine), $2 \%$ fetal bovine serum (FBS), $100 \mathrm{U} / \mathrm{ml}$ of penicillin, and $100 \mu \mathrm{g} / \mathrm{ml}$ of streptomycin (Invitrogen)]. Contaminating red blood cells were removed with blood lysis buffer $\left(0.15 \mathrm{M} \mathrm{NH}_{4} \mathrm{Cl}, 0.01 \mathrm{M} \mathrm{KHCO}_{3}, 0.1\right.$ mM EDTA, pH 7.3) if present. The cells were spun down and resuspended in fresh growth medium and seeded in cell culture plates or slide chambers. Two hours after seeding, the cultures were washed with PBS to remove unadherent cells, and fresh growth media was applied to establish primary cultures. When comparing macrophages harvested from Apoe ${ }^{-1-}$, apoE2, apoE3, and apoE4 mice, cultures were maintained in a medium supplemented with $2 \%$ lipoprotein-deficient FBS (Invitrogen). Experiments were performed $0-2 \mathrm{~d}$ after the cells were seeded and cultures were at least $90 \%$ pure as determined by staining with the macrophage specific markers F4/80, CD11b, or CD68. All animal experiments were approved by the Institutional Animal Care and Use Committee, Lilly Research Laboratory, Eli Lilly and Company.

$A \beta$ degradation by macrophage condition media. To prepare macrophage-conditioned media (MCM), macrophages were isolated as described above and incubated in media for $24 \mathrm{~h}$ that was then replaced with serum-free media [RPMI 1640, 0.3\% BSA (Invitrogen), $100 \mathrm{U} / \mathrm{ml}$ of penicillin and $100 \mu \mathrm{g} / \mathrm{ml}$ of streptomycin] and cultured for an additional $96 \mathrm{~h}$. The MCM was harvested and cleared by centrifugation at $1500 \mathrm{rpm}$. Brain sections from a very old PDAPP mouse or $1 \mathrm{ng} / \mathrm{ml}$ of freshly dissolved A $\beta 42$ (AnaSpec) was then incubated with control media (prepared in parallel to MCM but without the addition of cells), MCM, or MCM heated to $90^{\circ} \mathrm{C}$ for $15 \mathrm{~min}$ for $96 \mathrm{~h}$. A $\beta 42$ levels in the media or remaining in the PDAPP brain section were assessed by ELISA as described below.

In vitro $A \beta$ degradation assay. Macrophages were plated in 48-well plates at a density of $3 \times 10^{5}$ cells/well. The cells were cultured overnight and then switched to serum-free media with freshly dissolved A $\beta 42$ (3.0 $\mu \mathrm{g} / \mathrm{ml}$; AnaSpec) and the indicated treatment for the indicated times. After incubation, the culture media were collected, and $A \beta 42$ levels were measured by ELISA (Johnson-Wood et al., 1997). The cells were washed with PBS and lysed in $70 \mu \mathrm{l}$ of $5.5 \mathrm{M}$ guanidine- $\mathrm{HCI}(\mathrm{GuHCl})$, and $\mathrm{A} \beta$ was measured by ELISA.

$A \beta 42$ internalization assay. Internalization of $\mathrm{A} \beta 42$ by macrophages was assayed as described previously (Chung et al., 1999) with the follow- ing modifications: fluorescently labeled $\mathrm{A} \beta 42$ (FAM-A $\beta 42$; AnaSpec) was dissolved in DMSO, immediately aliquoted, and stored at $-80^{\circ} \mathrm{C}$. Macrophages were seeded in 4-well slide chambers at a density of $2 \times 10^{5}$ cells/well and incubated with $1 \mu \mathrm{g} / \mathrm{ml}$ FAM-A $\beta 42$ and the indicated treatment in serum-free medium for the indicated times. Cells were rinsed with $\mathrm{PBS}$ to remove any $\mathrm{A} \beta 42$ that was not bound or taken up and incubated with a monoclonal antibody specific to F4/80, or LAMP-1 (BD Pharmingen; $1: 100$ ). A $\beta$ uptake was determined by quantifying FAMA $\beta 42$ fluorescence that colocalized with the F4/80 or LAMP-1 markers by immunofluorescence or confocal microscopy in at least three randomized fields per treatment using Image-Pro Plus software.

Ex vivo $A \beta$ degradation assay. Homozygous transgenic PDAPP (Games et al., 1995), 22-26 months of age, were perfused with heparinized saline (2500 IU/L). The brains were removed and frozen in liquid nitrogen and stored at $-80^{\circ} \mathrm{C}$ until sectioning. Sagittal sections ( 10 or 16 $\mu \mathrm{m}$ ) were cut on a CM 3050-S cryostat (Leica), mounted on to poly-Llysine coated coverslips, transferred to 2 -well chamber slides, and used immediately or stored at $-80^{\circ} \mathrm{C}$ until use. Freshly harvested peritoneal macrophages were seeded in the chamber on top of sections at a density of $1 \times 10^{6}$ cells in $1 \mathrm{ml}$ of medium at $37^{\circ} \mathrm{C}$ for the indicated times (Koistinaho et al., 2004). This assay was further modified to physically separate macrophages from the PDAPP brain section by plating the cells on the bottom of culture dishes and placing the coverslip mounted sections in a Millicell-PCF culture plate insert (Millipore Bioscience Research Reagents). For inhibition of macrophage-mediated $\mathrm{A} \beta$ degradation by various reagents, cultures were coincubated for the indicated times with or without $75 \mu \mathrm{g} / \mathrm{ml}$ anti-apoE antibody (Biodesign), 50 $\mu \mathrm{g} / \mathrm{ml}$ anti-MMP-9 antibody (G657; Cell Signaling Technology), $10 \mu \mathrm{M}$ MMP-9 inhibitor (MMP-2/9 inhibitor I; Calbiochem), or $50 \mu \mathrm{g} / \mathrm{ml}$ RAP (a generous gift from Dr. G. Bu, Washington University, St. Louis, MO). After incubation, $A \beta$ present in the media was measured by ELISA as described below. The sections were washed with $1 \mathrm{ml}$ of PBS and analyzed by ELISA, immunohistochemistry (IHC), or thioflavine-S staining.

Human A $\beta$ ELISA. A $\beta$ levels in media, or $\mathrm{GuHCl}$ lysates from cells or sections ( $200 \mu \mathrm{l}$ of $5.5 \mathrm{M} \mathrm{GuHCl} /$ section) were assayed as described previously (Johnson-Wood et al., 1997; Bales et al., 1999). In brief, guanidine-solubilized samples were diluted with Casein blocking buffer (Pierce) to a final concentration of $0.5 \mathrm{M} \mathrm{GuHCl}$ or less. Samples were loaded onto plates coated with an antibody that specifically recognizes the $\mathrm{C}$-terminal domain of $\mathrm{A} \beta 42(21 \mathrm{~F} 12)$ as a capture, and biotinylated 3D6 (A $\beta 42)$ or biotinylated $266(\mathrm{~A} \beta \mathrm{x}-42)$ was used for detection. The signal after incubation with HRP-conjugated streptavidin (Research Diagnostics), the signal was developed with TMB substrate (Pierce) and read on a SpectraMAX 190 plate reader (Molecular Devices).

Immunohistochemistry. After the indicated treatment, the cells were fixed with $4 \%$ paraformaldehyde and blocked with $0.5 \%$ BSA in $0.2 \%$ Triton X-100/PBS for $30 \mathrm{~min}$. Cells or sections were then incubated with anti-F4/80 (Serotec; 1:100), anti-CD68 (BD Pharmingen; 1:100), antiMMP-9 (Santa Cruz Biotechnology; 1:50), or anti-A $\beta$ antibody (3D6; $1: 1000$ ) overnight at $4^{\circ} \mathrm{C}$, washed with PBS with $0.1 \%$ Tween-20 (PBST) three times, and incubated with secondary antibodies conjugated to AlexaFluor 488 or 594 (Invitrogen) for $1 \mathrm{~h}$ at room temperature. The slides were washed with PBST three times and then coverslipped with VECTASHIELD HardSet Mounting Medium with 4', 6'-diamidino-2phenylindole dihydrochloride (DAPI; Vector Laboratories). Representative images were captured using a fluorescence imaging system (Leica), and images from three randomized fields per treatment group were quantified using an Image-Pro Plus software program (Media Cybernetics) written in Image-Pro scripting language and run under Image-Pro Plus 4.5.0.29 (Bales et al., 1999; Koistinaho et al., 2004).

To measure $\mathrm{A} \beta$ burden by IHC, sections were fixed with $4 \%$ paraformaldehyde (Electron Microscopy Sciences) and probed with antibodies 3D6 (1:1000), pan $\beta$ amyloid antibody (Biosource;1:200) or CD68 (1: $100)$ and detected with fluorescent-conjugated secondary antibodies. Thioflavine-S staining was performed as described previously (Bales et al., 1997). Briefly, fixed sections were incubated with $1 \%$ freshly made thioflavine-S for $8 \mathrm{~min}$ and then cleared with $80 \%$ ethanol for $1 \mathrm{~min}$, followed by washing with $\mathrm{H}_{2} \mathrm{O}$ two times for 1 min each. The percentage area of the hippocampus occupied by 3D6 label (A $\beta$ burden) or 
A

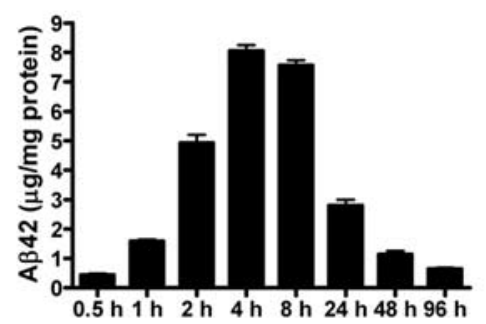

C
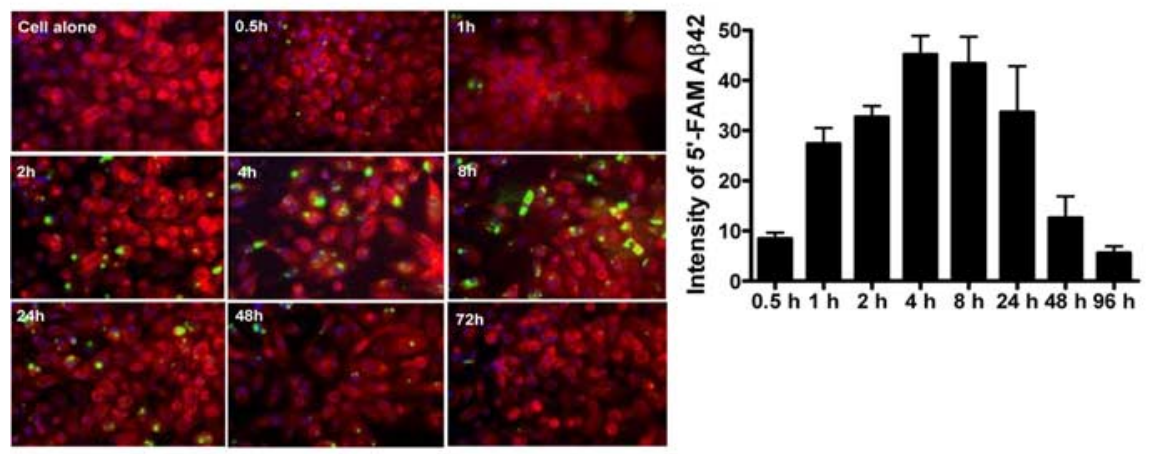

E
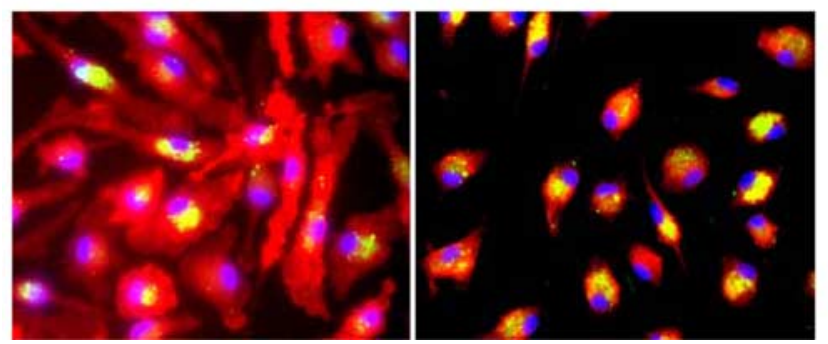

Figure 1. Macrophages degrade exogenous $A \beta 42$. Human $A \beta 42(3 \mu \mathrm{g} / \mathrm{ml})$ was incubated with macrophages for the indicated times. $\boldsymbol{A}-\boldsymbol{C}, A \beta 42$ levels in the cell pellet $(\boldsymbol{A})$ or in the media $(\boldsymbol{B})$ after incubation were measured by ELISA. FAM-A $\beta 42$ (1 $\mu \mathrm{g} / \mathrm{ml}$; green) was incubated with macrophages (labeled red with F4/80) for the indicated times ( $\boldsymbol{C}$. Cell nuclei were visualized by DAPI (blue). Original magnification, $40 \times$. D, The intensity of intracellular FAM-A $\beta 42$ was quantified using Image-Pro Plus software. $\boldsymbol{E}$, Colocalization (yellow) of FAM-A $\beta 42$ (green) with macrophages (red; left panel) or the endosomal/lysosomal marker LAMP-1 (red; right panel). Macrophages were incubated with $1 \mu \mathrm{g} / \mathrm{ml} \mathrm{FAM-A} \beta 42$ for $2 \mathrm{~h}$ and imaged with fluorescence microscopy. Cell nuclei were visualized with DAPI (blue). Original magnification, $40 \times$. Representative data from one experiment that was repeated three times with similar results. Error bars represent the SE measurement.

thioflavine-S positive $A \beta$ deposits (amyloid burden) was calculated from images captured from six to eight sections per treatment group using the Image-Pro Plus software program.

Mass spectrometry. A $\beta 42$ was measured in brain sections that were solubilized by $\mathrm{GuHCl}(20 \mu \mathrm{l})$ from the ex vivo assay, diluted in $1 \mathrm{ml}$ of RPMI-1640, and spiked with an internal peptide standard [15NA $\beta 40$ (R-peptide)]. Immunoprecipitation and matrix-assisted laser desorption/ionization (IP-MALDI) mass spectrometry was performed as described previously (Gelfanova et al., 2007).

Gelatin-substrate zymography. MMP-9 enzyme activity from culture media was assayed by zymography using Novex Zymogram Gelatin Gels (Invitrogen) according the manufacturer's instructions. For detection of MMP activity, the zymogram gels were stained with SimplyBlue SafeStain (Invitrogen) and then destained with water. Enzyme activity attributed to MMP-9 or MMP-2 was visualized (on the basis of molecular weight) in the gelatin-containing zymograms as clear bands against a blue background (Leber and Balkwill, 1997). The gels were imaged by MagicScan, and quantification was performed by scanning densitometry (KDSOD 2.0).

Intracerebral injection of macrophages. Macrophages were prepared from apoE2 or apoE4 targeted replacement mice as described above. Immediately before intracerebral injection, macrophages were centrifuged at $1500 \mathrm{rpm}$ for $5 \mathrm{~min}$ and resuspended in artificial CSF (Swanson et al., 2004) at a cell density of $0.5 \times 10^{6}$ cells $/ \mu$ l. Seven heterozygous mice $(\mathrm{C} 57 \mathrm{BL} / 6 \times$ PDAPP, 28 months of age) were anesthetized with Avertin $(0.025 \mathrm{ml} / \mathrm{g}$ body weight) and immobilized in a stereotaxic apparatus (Stoelting). Macrophages $(2 \mu \mathrm{l})$ were injected at a rate of $0.2 \mu \mathrm{l} / \mathrm{min}$ into the cerebral cortex at the following coordinates from the bregma: anterior/posterior, $0.0 \mathrm{~mm}$; mediolateral: $\pm 1.5 \mathrm{~mm}$; dorsoventral: $1.5 \mathrm{~mm}$ below skull surface. The apoE2 macrophages were injected into the right hemisphere and E4 macrophages into the contralateral side of the same mouse. Two minutes after injection, the needle was slowly withdrawn. Animals were monitored until they regained full consciousness. Three days after injection of cells, the mice were terminally anesthetized with Avertin and perfused with heparinized saline (2500 IU/L) for 2 min (Takata et al., 2007; Pihlaja et al., 2008). The brains were removed and frozen in liquid nitrogen and stored at $-80^{\circ} \mathrm{C}$ until sectioning. Brain $\mathrm{A} \beta$ burden was determined as described above. The removal of $A \beta$ from the cortex by injected macrophages was calculated as the difference between $\mathrm{A} \beta$ burden proximal to the injection site and the amount of $\mathrm{A} \beta$ remaining within the injection site.

Statistical analyses. To compare differences between the experimental groups, a two-tailed $t$ test or one-way ANOVA followed by the TukeyKramer test for multiple comparisons were performed using GraphPad Prism software.

\section{Results}

Macrophages efficiently phagocytose and degrade exogenous $\mathrm{A} \boldsymbol{\beta}$

To determine if macrophages can internalize and degrade $\mathrm{A} \beta$, we coincubated peritoneal macrophages from WT mice with human $A \beta 42$ and measured the amount of cell-associated $A \beta 42$ as well as the amount remaining in the media using a sensitive ELISA (Fig. 1). Cell-associated $\mathrm{A} \beta 42$ increased in a time-dependent manner with maximal levels measured at $4 \mathrm{~h}$ after incubation with human $\mathrm{A} \beta 42$ and decreased by $>90 \%$ over the ensuing $96 \mathrm{~h}$ (Fig. $1 A$; supplemental Fig. $1 A$, available at www.jneurosci.org as supplemental material). In contrast, $A \beta 42$ that could be measured in the media decreased in a time-dependent manner, such that $<15 \%$ remained after $96 \mathrm{~h}$ of incubation (Fig. $1 B$; supplemental Fig. $1 B$, available at www.jneurosci.org as supplemental material). Incubation of $A \beta 42$ in media alone (without the addition of macrophages) over the same time course did not result in any significant decrease in the level of A $\beta 42$ measured by our ELISA (over $90 \%$ of the $A \beta 42$ that was measured in the media after incubation could be recovered) (supplemental Fig. $1 C, D$, available at www. jneurosci.org as supplemental material). A $\beta 42$ incubated with or without macrophages for up to $96 \mathrm{~h}$ primarily remains monomeric; however, a small amount of oligomeric $\mathrm{A} \beta(<17 \mathrm{kDa})$, but no fibrillar A $\beta$ or amyloid, could be detected (supplemental Fig. 1 E- G, available at www.jneurosci.org as supplemental material). Incubation of 
A $\beta 42$ with peritoneal macrophages dramatically reduces the amount of both $\mathrm{A} \beta$ monomer and oligomers (supplemental Fig. 1E, available at www.jneurosci.org as supplemental material). These data demonstrate that macrophages are able to efficiently internalize and degrade human $\mathrm{A} \beta 42$.

We next investigated the intracellular localization of $A \beta 42$ after uptake by macrophages. Using FAM-A $\beta 42$ coincubated with macrophages from WT mice, we observed a time-dependent uptake of $\mathrm{A} \beta 42$ and observed that the FAM-labeled A $\beta 42$ was associated with the macrophage marker F4/80 (Fig. $1 C-E$ ). That the $\mathrm{A} \beta 42$ was internalized by the macrophages was confirmed by confocal microscopy (supplemental Fig. 2A, $B$, available at www. jneurosci.org as supplemental material). Additionally, FAM-A $\beta 42$ that was internalized by macrophages was clearly associated with the lysosomal marker LAMP-1 (Fig. 1E; supplemental Fig. 2C, available at www.jneurosci.org as supplemental material).

\section{Macrophages efficiently degrade A $\beta$ ex vivo}

Because $\mathrm{A} \beta$ deposited in brain parenchyma represents a conformationally diverse set of peptides, we used an ex vivo assay in which we incubated peritoneal macrophages collected from WT mice on top of unfixed brain sections from old PDAPP transgenic mice to determine if macrophages could degrade various $A \beta$ species that were deposited in brain (Fig. 2 ). Brain sections from very old PDAPP transgenic mice contain abundant $A \beta$ deposits that are predominantly composed of nonfibriallar $\mathrm{A} \beta 42$ and a small percentage $(\sim 0.3 \%)$ of amyloid (thioflavine-Spositive $\mathrm{A} \beta$ deposits). A considerable amount of $\mathrm{A} \beta$ characterized as monomeric or oligomeric $A \beta$ species present in sections can be solubilized by culture media or other aqueous solutions (data not shown). After incubation with macrophages, we observed a time-dependent decrease in the amount of $A \beta 42$ in PDAPP brain sections [thoroughly solubilized by guanidine- $\mathrm{HCl}$ (supplemental Fig. 3, available at www.jneurosci.org as supplemental material)] such that only $58 \%$ of the $\mathrm{A} \beta 42$ remaining in the section could be measured $48 \mathrm{~h}$ after incubation (Fig. $2 A$ ). More striking, however, was the nearly complete loss of $\mathrm{A} \beta 42$ in brain sections when macrophages were incubated for 96 h (Fig. 2A). Importantly, there was a parallel time-dependent decrease in the amount of $\mathrm{A} \beta 42$ that could be measured in the media, indicating that macrophages can also efficiently degrade soluble forms of $A \beta$ released from the brain section into the media (Fig. $2 B$ ). Additionally, the level of brain $\mathrm{A} \beta$ burden as measured by quantitative IHC decreased proportionately (Fig. 2C) (92.7 $\pm 9.5 \%$ decrease) (sup-

A

C
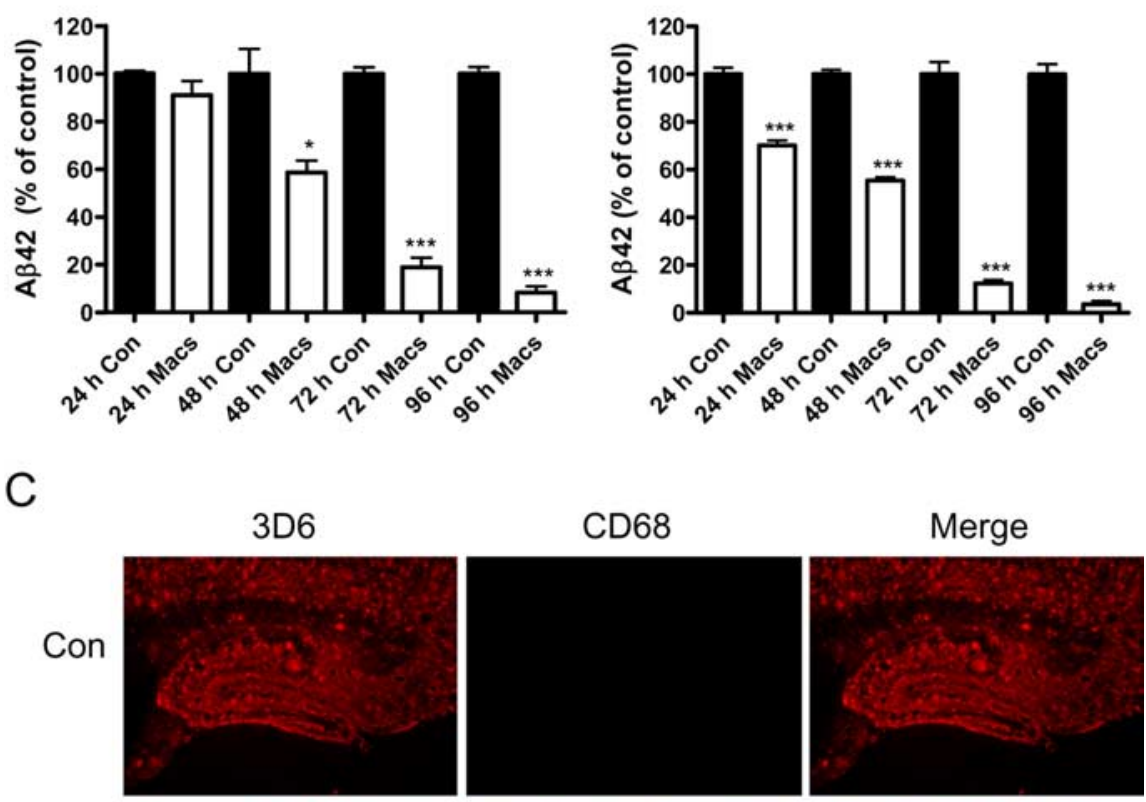

Macs

Figure 2. Macrophages efficiently degrade A $\beta$ in situ. Brain sections from old PDAPP mice were incubated with (Macs) or without (Con) macrophages for the indicated times. $A-C, A \beta 42$ remaining in brain sections $(\boldsymbol{A})$ or released into the media $(\boldsymbol{B})$ was measured by ELISA and plotted as a percentage of the control value. Representative PDAPP brain sections incubated with (Macs; bottom) or without (Con; top) macrophages for $96 \mathrm{~h}$ and immunostained for $\mathrm{A} \beta$ with the anti-A $\beta$ antibody $3 \mathrm{D} 6$ (red) and the macrophage-selective marker CD68 (green; C). Original magnification, $5 \times$. D, Representative photomicrograph demonstrating amyloid deposits stained with thioflavine-S (green) in the hippocampus of PDAPP mouse brain sections after incubation with Macs) or without (Control) macrophages for $96 \mathrm{~h}$. Original magnification, $5 \times . n=6$ sections/treatment; ${ }^{*} p<0.05,{ }^{* * *} p<$ 0.001 versus control. Representative data from one experiment that was repeated three times with similar results. Error bars represent the SE measurement. plemental Fig. 4, available at www.jneurosci.org as supplemental material) $(n=6$ sections per treatment; $p<0.001)$. Similarly, when fibrillar $\mathrm{A} \beta$ deposits (thioflavine-S-positive amyloid) were quantified, the number of amyloid plaques remaining $96 \mathrm{~h}$ after PDAPP brain sections was $<5 \%$ of that quantified in untreated sections (Fig. $2 D)(98.1 \pm 20.3 \%$ reduction; $n=4$ sections per treatment; $p<0.01)$. Thus, macrophages very efficiently degrade virtually all deposited and soluble species of $\mathrm{A} \beta$, including frank amyloid. We caution, however, that the various $\mathrm{A} \beta$ species present even in our ex vivo assay using PDAPP brain sections may still differ from those present in human $\mathrm{AD}$ brain. 
A
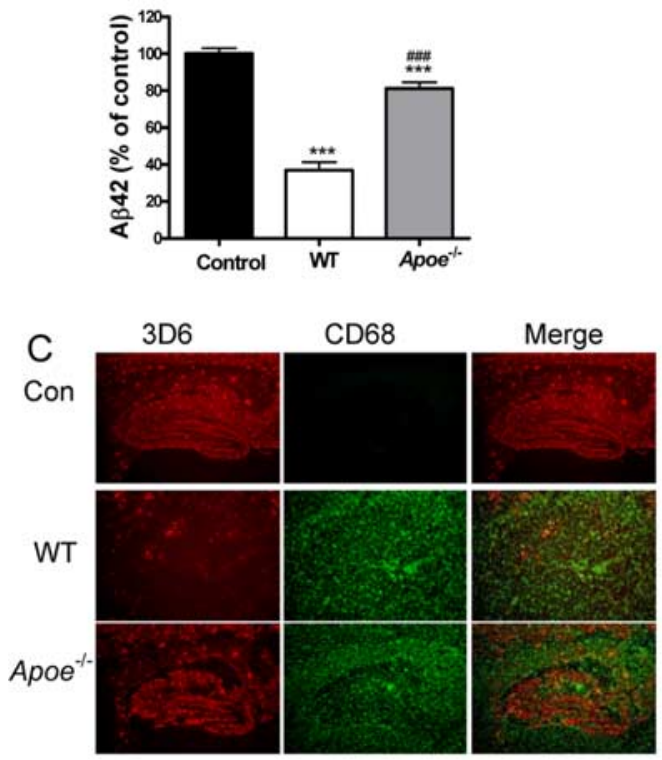

$E$

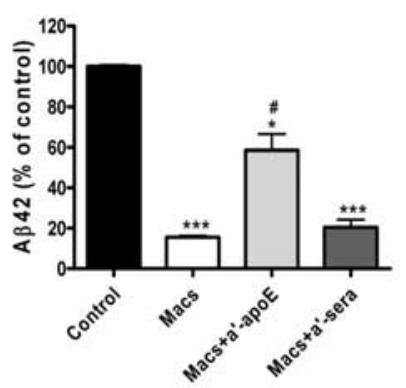

G

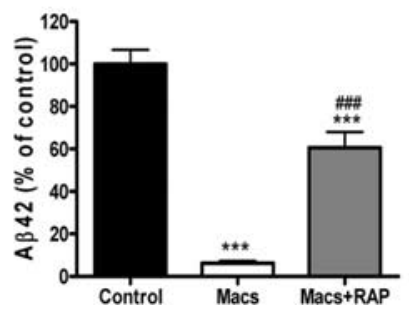

B
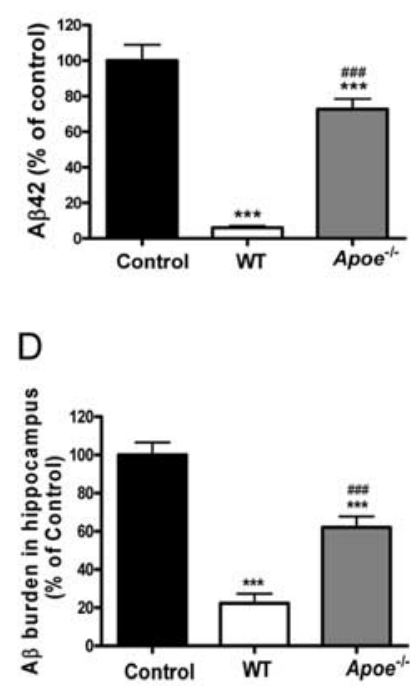

$\mathrm{F}$

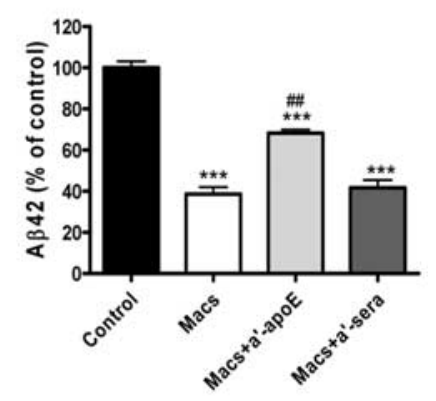

$\mathrm{H}$

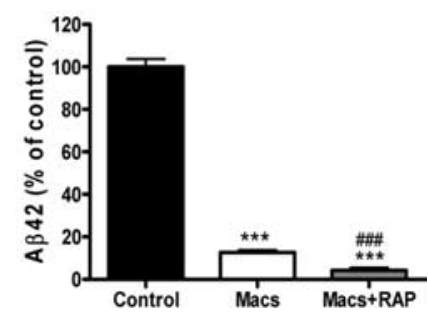

Figure 3. ApoE-dependent degradation of $A \beta$ by macrophages. PDAPP brain sections were incubated with macrophages isolated from WT or Apoe-deficient (Apoe ${ }^{-1-}$ ) mice for $96 \mathrm{~h}$. Adjacent PDAPP brain sections were incubated with media alone as control (Control). $\boldsymbol{A}-\boldsymbol{C}, A \beta$ levels remaining in the sections $(\boldsymbol{A})$ or released into the media $(\boldsymbol{B})$ were measured by ELISA and are presented as a percentage of control value. Representative PDAPP brain sections incubated with WT macrophages (WT), ApoEdeficient macrophages (Apoe ${ }^{-I-}$ ), or media alone (Con) for $96 \mathrm{~h}$ and immunostained for $A \beta$ with the anti-A $\beta$ antibody 3D6 (red) and the macrophage-selective marker CD68 (green; C). Original magnification, $5 \times$. D, Quantification of brain $A \beta$ burden after incubation of PDAPP brain sections with macrophages. $n=6$ sections per treatment; ${ }^{* * *} p<0.001$ versus control; \#\#\# $p<$ 0.001 versus WT. $\boldsymbol{E}-\boldsymbol{H}$, PDAPP mouse brain sections were incubated with macrophages alone (Macs), macrophages plus a polyclonal rabbit anti-ApoE antibody (Macs $+\mathrm{a}^{\prime}-A p o E ; 75 \mu \mathrm{g} / \mathrm{ml}$ ), an anti-rabbit sera (Macs $+\mathrm{a}^{\prime}$-sera; $\left.75 \mu \mathrm{g} / \mathrm{ml}\right)(\boldsymbol{E}, \boldsymbol{F})$, or RAP $($ Macs + RAP; $50 \mu \mathrm{g} / \mathrm{ml})(\boldsymbol{G}, \boldsymbol{H})$ for $96 \mathrm{~h}$. A $\beta$ remaining in the sections $(\boldsymbol{E}, \boldsymbol{G})$ or released into the media $(\boldsymbol{F}, \boldsymbol{H})$ were quantified by ELISA and plotted as a percentage of control value. $n=6$ sections per treatment; ${ }^{*} p<0.05$, ${ }^{* * *} p<0.001$ versus media only

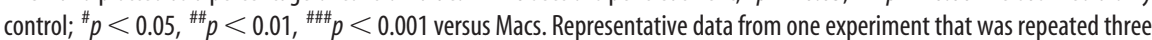
times with similar results. Error bars represent the SE measurement.

\section{Macrophages degrade A $\beta$ in situ in an} apoE-dependent manner

We previously reported that astrocytes are able to degrade brain $\mathrm{A} \beta$ via an apoE-dependent mechanism (Koistinaho et al., 2004).
Because macrophages also synthesize and secrete apoE, we next investigated whether macrophage-mediated $A \beta$ degradation was dependent on apoE. When PDAPP brain sections were incubated for $96 \mathrm{~h}$ with macrophages prepared from apoEdeficient mice, we observed only a modest decrease in the levels of $A \beta 42$ remaining in both the brain section and media (Fig. $3 A, B)$. In contrast, and as previously observed, WT macrophages were able to efficiently degrade $\mathrm{A} \beta 42$ in both the PDAPP brain sections as well as media, and the differences between the apoE-deficient and WT mouse macrophages were statistically significant (Fig. $3 A, B$ ). Consistently, hippocampal $\mathrm{A} \beta$ immunoreactivity in old PDAPP brain sections was reduced by $>80-90 \%$ after incubation for $96 \mathrm{~h}$ with WT mouse macrophages and only by $\sim 60 \%$ when adjacent brain sections were incubated with apoE-deficient macrophages (Fig. 3C,D).

To further confirm a role for apoE in macrophage-mediated $A \beta$ degradation, we coincubated WT mouse macrophages with rabbit anti-mouse apoE antisera just before incubation with a PDAPP mouse brain section (Fig. $3 E, F$ ). In the presence of normal medium or normal rabbit sera, macrophages effectively reduced $\mathrm{A} \beta 42$ levels in the sections (Fig. 3E), as well as in the media (Fig. 3F). However, when macrophages were coincubated with sections and rabbit anti-mouse apoE antisera, the degradation of $A \beta$ by macrophages was reduced by $\geq 50 \%$ (Fig. $3 E, F$ ).

Next, we investigated whether the LDL receptor antagonist, RAP, could block the ability of macrophages to degrade $A \beta$ in PDAPP brain sections or $A \beta$ released into the media. When macrophages were coincubated with brain sections from old PDAPP mice and RAP, there was a reduction in the ability of macrophages to degrade $A \beta$ deposited in the brain section, but not in their ability to degrade soluble $\mathrm{A} \beta$ released into the media (Fig. $3 G, H$ ). When macrophages were incubated with FAM-labeled $\mathrm{A} \beta$, RAP very modestly reduced the cell-associated/ uptake of FAM-labeled A $\beta$ after $2 \mathrm{~h}$ incubation and also significantly inhibited its degradation after $96 \mathrm{~h}$ (supplemental Fig. $5 A, B$, available at www.jneurosci.org as supplemental material). In contrast, incubation with RAP increased $A \beta$ degradation in the media when macrophages were incubated with $\mathrm{A} \beta$ for shorter time points $(4,24$, and $72 \mathrm{~h}$ ) (supplemental Fig.5C, availableat www. jneurosci.org as supplemental material). Together, these data suggest that macrophages may employ independent mechanisms for degrading soluble and insoluble $A \beta$ and that degradation of insoluble $\mathrm{A} \beta$ involves one or more LDL receptors. 
Macrophages degrade $A \beta 42$ via an apoE isoform-dependent mechanism

Since we established that macrophages can internalize and degrade soluble as well as deposited A $\beta 42$ via an apoE-dependent mechanism, we next investigated whether there was an apoE isoform-dependent difference in the ability of macrophages to efficiently degrade $\mathrm{A} \beta$ (Fig. 4). Macrophages were prepared from apoE-targeted replacement mice expressing one of the three human apoE isoforms. When macrophages from apoE2-, apoE3-, or apoE4targeted replacement mice were coincubated with PDAPP brain sections, there was a significant apoE isoform-dependent difference in the ability of macrophages to degrade $A \beta 42$ in both brain sections and media such that apoE2-expressing macrophages degrade $A \beta 42$ more efficiently than either apoE3- or apoE4-expressing macrophages (E2 $\gg$ E3 $>$ E4) (Fig. 4). After $48 \mathrm{~h}$ of incubation with PDAPP brain sections and apoE2 macrophages, nearly $50 \%$ of the $\mathrm{A} \beta 42$ had been degraded, whereas only $\sim 20 \%$ of $A \beta 42$ was degraded after coincubation with apoE3-expressing macrophages and virtually no $\mathrm{A} \beta 42$ was degraded when PDAPP brain sections were coincubated with macrophages collected from apoE4-expressing mice (Fig. $4 A, B)$. By $96 \mathrm{~h}$ after incubation, all three apoE isoform-expressing macrophages were able to degrade both deposited and soluble $\mathrm{A} \beta 42$, but a similar isoformdependent difference $(\mathrm{E} 2>\mathrm{E} 3>\mathrm{E} 4)$ was observed (Fig. $4 A, B$ ). We further confirmed the apoE isoform-dependent deg-

radation of $\mathrm{A} \beta 42$ by macrophages using a quantitative IPMALDI analysis. Similar to the results observed when A $\beta 42$ was measured by our sensitive ELISA, there was a significant apoE isoform-dependent decrease in the amount of $A \beta 42$ that was recovered $96 \mathrm{~h}$ after macrophages derived from apoE-targeted replacement mice were incubated with PDAPP brain sections with the most robust and efficient degradation observed with macrophages expressing human apoE2 (Fig. 4C; supplemental Fig. 6, available at www.jneurosci.org as supplemental material). Incubation of FAM-labeled $A \beta$ with macrophages for $2 \mathrm{~h}$ did not reveal a significant difference in cell-associated $A \beta 42$ in apoE2versus apoE4-expressing macrophages, suggesting that the initial uptake of $\mathrm{A} \beta$ by macrophages is not affected by apoE isoforms. However, there was much more degradation of $\mathrm{A} \beta$ in apoE2expressing versus apoE4-expressing macrophages after $96 \mathrm{~h}$ of incubation (supplemental Fig. 7, available at www.jneurosci.org as supplemental material), consistent with our ex vivo assay results, indicating the contribution of a mechanism independent of $\mathrm{A} \beta$ internalization involved in apoE isoform-specific effects in $\mathrm{A} \beta$ degradation by macrophages.

\section{Macrophages can degrade $A \beta$ in vivo}

We next examined whether apoE2-expressing macrophages differ from apoE4-expressing macrophages in their ability to degrade human $\mathrm{A} \beta$ after direct intracerebral injection into mouse
$\mathrm{B}$

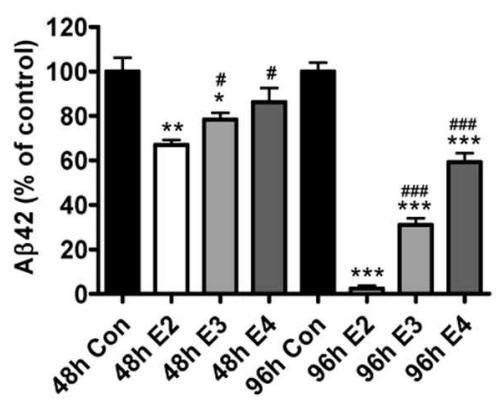

$\mathrm{D}$

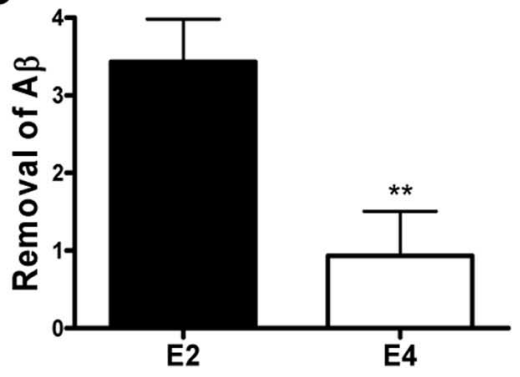

Figure 4. Macrophages degrade $A \beta 42$ via an apoE isoform-dependent manner. Macrophages isolated from targeted replacement mice expressing human apoE2 (E2), apoE3 (E3), or apoE4 (E4) were incubated with PDAPP mouse brain sections for 48 or incubation with E2, E3, or E4 macrophages for $96 \mathrm{~h}$ was verified by quantitative IP-MALDI analysis. $n=6$ sections per treatment; ${ }^{* * *} p<0.001$ versus control; ${ }^{\#} p<0.05,{ }^{\# \#} p<0.01$ versus $\mathrm{E2}$ macrophages. $\mathrm{E2}$ or $\mathrm{E} 4$ macrophages were administered bilaterally ( $0.5 \times 1{ }^{6}$ (ells) via intracerebral injection into the right or left cerebral cortices, respectively, of old heterozygous PDAPP mice (28 months). $\boldsymbol{D}$, Three days after injection, brain $A \beta$ was calculated as the difference between $A \beta$ burden proximal to the injection site and the amount of $A \beta$ remaining within the injection site. $n=7$ animals. ${ }^{* *} p<0.01$ versus $E 2$ injection sites. Representative data from one experiment that was repeated two times with similar results. Error bars represent the SE measurement.

brain. Macrophages expressing human apoE2 or apoE4 were administered bilaterally $\left(0.5 \times 10^{6}\right.$ cells $)$ via intracerebral injection into the right or left cortices of old PDAPP mice. Three days after intracerebral injection, $A \beta$ immunoreactivity in the area injected with apoE2-expressing macrophages was significantly lower when compared with the contralateral side injected with apoE4expressing macrophages (Fig. $4 D$; supplemental Fig. 8, available at www.jneurosci.org as supplemental material).

\section{Macrophages secrete A $\boldsymbol{\beta}$ degrading enzymes}

To first address whether $A \beta 42$ degradation induced by macrophages requires a physical association with the cells, we cultured macrophages on the bottom of a culture dish that was physically separated from the PDAPP brain section by a filter. We then measured $\mathrm{A} \beta 42$ remaining in the brain section and released into the media (Fig. $5 A, B$ ). A significant decrease in the level of $A \beta 42$ remaining in the brain section or released into the media was observed. Less than $50 \%$ of the $\mathrm{A} \beta 42$ could be detected in the brain section, and nearly $90 \%$ of the $A \beta 42$ that was released into the media was degraded even when macrophages were prevented from physically associating with the brain section itself, suggesting that $\mathrm{A} \beta 42$ degradation induced by macrophages does not require a physical association with the cells (Fig. $5 A, B$ ). We next collected conditioned media from macrophages (MCM) that had been in culture for $96 \mathrm{~h}$ and incubated the MCM with either 
A

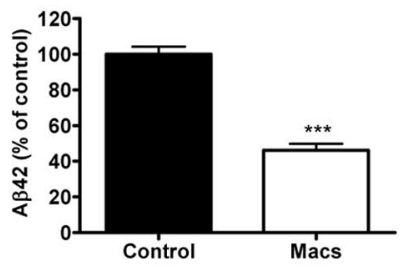

B

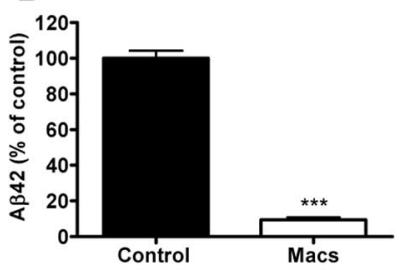

C
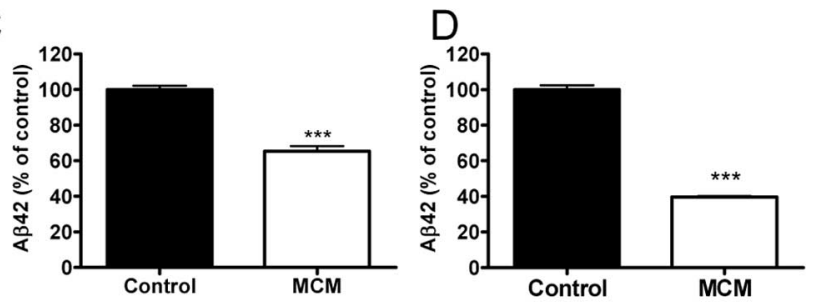

E

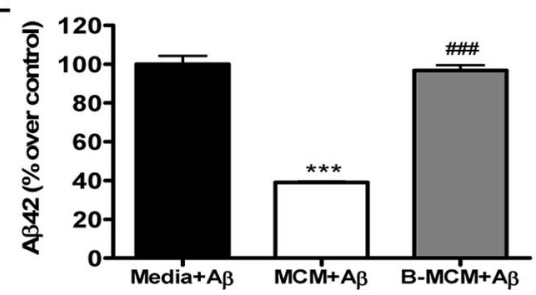

Figure 5. Macrophages secrete $A \beta$ degrading enzymes. Macrophages were physically blocked from associating with PDAPP brain sections by using the modified ex vivo assay (as described in Materials and Methods). $\boldsymbol{A}, \boldsymbol{B}, \mathrm{A} \beta 42$ remaining in the sections ( $\boldsymbol{A}$ ) or released into the media $(\boldsymbol{B})$ after $96 \mathrm{~h}$ of incubation with (Macs) or without (Control) macrophages was measured by ELISA and are presented as a percentage of control value. $n=6$ sections per treatment; ${ }^{* * *} p<0.001$ versus control. Representative data from one experiment that was repeated three times with similar results. PDAPP mouse brain sections $(10 \mu \mathrm{m})$ were incubated with conditioned media from macrophages (MCM) or serum-free media (Control) for $96 \mathrm{~h} . C, D$, $A \beta$ remaining in the brain sections $(\boldsymbol{C})$ or released into the media $(\boldsymbol{D})$ was measured by ELISA and plotted as a percentage of control value. $E$, MCM spiked with human A $\beta 42$ (Anaspec; 1 $\mathrm{ng} / \mathrm{ml}$ ) efficiently degrades $A \beta 42$. The $A \beta 42$ degradation activity of $M C M$ is lost after boiling (B-MCM). $n=6$ sections per treatment; ${ }^{* * *} p<0.001$ versus medium only control; ${ }^{\# \#} p<$ 0.001 versus $M C M$ plus $A \beta$. Representative data from one experiment that was repeated three times with similar results. Error bars represent the SE measurement.

human $\mathrm{A} \beta 42$ or PDAPP brain sections (Fig. $5 C-E$ ). When MCM was incubated with human $\mathrm{A} \beta 42$ or PDAPP brain sections, there was a significant decrease in the amount of $\mathrm{A} \beta 42$ that could be measured. Heat treatment of MCM $\left(90^{\circ} \mathrm{C}, 15 \mathrm{~min}\right)$ completely eliminated the observed $\mathrm{A} \beta$ degrading activity (Fig. $5 E$ ).

\section{Secretion of matrix metalloproteinase- 9 is associated with macrophage-dependent $\mathrm{A} \boldsymbol{\beta}$ degradation}

Multiple proteases have been reported to degrade $A \beta$, and each protease appears to have cleavage sites that generate unique $\mathrm{A} \beta$ fragments (Roher et al., 1994; Howell et al., 1995; Backstrom et al., 1996; Eckman et al., 2001; Kurochkin, 2001; Carson and Turner, 2002). We incubated freshly dissolved synthetic human A $\beta 42$ with macrophages for 2 and $72 \mathrm{~h}$ and then analyzed the culture medium and cell pellets by MALDI time-of-flight mass spectrometry. Incubation of A $\beta 42$ with macrophages resulted in a significant decrease in the levels of full-length $A \beta 42$ and with the concomitant appearance of several $\mathrm{A} \beta$ fragments in the media $(\mathrm{A} \beta 1-19,1-20,1-22,1-23,1-28,1-34,1-38)$ and cell pellet (A $\beta 1-38,4-42)$. These $\mathrm{A} \beta$ fragments represent characteristic cleavage patterns resulting from the activity of MMP-9, neprilysin, insulin-degrading enzyme, endothelin-converting enzyme, and other enzymes (supplemental Fig. 9, available at www. jneurosci.org as supplemental material). Given the pattern and sequence of $A \beta$ peptides generated by macrophages after incubation with full-length $\mathrm{A} \beta 42$ and a recent report demonstrating that MMP-9 can degrade fibrillar A $\beta$ (Yan et al., 2006), we investigated whether MMP-9 could play a role in the macrophagedependent degradation of $\mathrm{A} \beta 42$ that we observed. When macrophages were coincubated with an anti-MMP-9 antibody and then plated on top of PDAPP brain sections, there was a significant reduction in the ability of macrophages to degrade $\mathrm{A} \beta$, both in the section and in the media (Fig. 6A,B). Coincubation with an anti-MMP-9 antibody reduced the ability of macrophages to degrade $\mathrm{A} \beta$ by $\sim 50 \%$ (Fig. 6 ). Additionally, when an MMP-9 inhibitor (MMP-2/9 inhibitor I, $10 \mu \mathrm{M}, 96 \mathrm{~h}$ ) was added to the cultures, there was a modest but significant inhibition in the ability of macrophages to degrade $\mathrm{A} \beta$ (Fig. $6 C, D$.)

We next determined if there was a difference in the level of MMP-9 protein expressed by macrophages expressing different human apoE isoforms using IHC. We observed significantly more MMP-9 protein in apoE2-expressing macrophages when compared with apoE3- or apoE4-expressing macrophages (Fig. $6 E$ ). We next measured the activity of MMP-9 in the media after macrophages from each of the three human apoE isoforms were incubated with or without a brain section from a very old PDAPP mouse using gelatin substrate zymography (Fig. 6F). Although the activity of MMP-9 was similar when measured in the media of cultures prepared from human apoE 2, 3, or 4 mice, there was a significant increase in the activity of MMP-9 in apoE2-expressing macrophages that had been coincubated with brain sections from very old PDAPP transgenic mice (Fig. $6 F$ ). In contrast, there was no significant difference in MMP-2 activity under the same incubation conditions (Fig. 6F).

\section{Discussion}

We have demonstrated that peritoneal macrophages very efficiently degrade soluble, insoluble/aggregated as well as more fibrillar forms of $\mathrm{A} \beta$ (i.e., thioflavine-S positive amyloid). Our findings confirm and extend a recent report by Majumdar et al. (2008), contrasting the ability of microglia which incompletely degrade fibrillar $\mathrm{A} \beta$ with that of macrophages. Like microglia, macrophages actively internalize $A \beta 42$ via a phagocytic mechanism and deliver it to lysosomes, where in contrast to microglia they nearly completely degrade all of the internalized $\mathrm{A} \beta$ (Fig. $1 A)$. However, using our ex vivo assay it is also clear that macrophage-induced $\mathrm{A} \beta$ degradation is due in good measure to secretion of one or more proteases (see below), because physical contact of macrophages with the $A \beta$-containing tissue sections is not required for the robust $A \beta /$ amyloid degradation. Moreover, MCM (devoid of intact macrophages) is quite efficient at degrading $\mathrm{A} \beta$, and this $\mathrm{A} \beta$-degrading activity is completely heat sensitive (Fig. 5).

We also delineated an important role for macrophage apoE expression in the ability of macrophages to degrade soluble and insoluble $\mathrm{A} \beta$. Compared with macrophages prepared from WT mice, those prepared from apoE-deficient mice displayed a markedly reduced ability to degrade $\mathrm{A} \beta$ over an identical time course. Moreover, the addition of anti-apoE antisera also reduced $\mathrm{A} \beta$ degradation in our ex vivo assay (Fig. $3 E, F$ ). It is important to emphasize that apoE-deficient macrophages can still degrade $\mathrm{A} \beta$ but at a markedly reduced rate. Finally, the ability of wild-type mouse macrophages to degrade $A \beta$ is blocked by coincubation with RAP, suggesting that one or more LDL receptors, which are well known receptors for apoE, are involved. Moreover, RAP was 
more effective at inhibiting the degradation of insoluble $\mathrm{A} \beta$ present in the PDAPP brain sections when compared with $A \beta$ released into the media (Fig. $3 G, H$ ), indicating a possible difference in the mecha$\operatorname{nism}(\mathrm{s})$ by which macrophages degrade $\mathrm{A} \beta$ released into the media and $\mathrm{A} \beta$ remaining in sections (e.g., cellular uptake vs secreted protease).

Because the $\varepsilon 4$ allele of $A P O E$ represents a major risk factor for late-onset $A D$, we investigated the ability of macrophages prepared from human apoE-targeted replacement transgenic mice to degrade $\mathrm{A} \beta$. Our data demonstrate that apoE2expressing macrophages were substantially more efficient at degrading $\mathrm{A} \beta$ than either apoE3- or apoE4-expressing macrophages $($ E2 $\gg$ E3 $>$ E4) (Fig. $4 A-C$ ). ApoE2-expressing macrophages also more efficiently degrade $A \beta$ when directly injected into the cerebral cortex of old PDAPP mice, confirming the apoE isoform-dependent nature of the underlying mechanism in vivo. Finally, given the ability of macrophages to degrade both nonfibrillar as well as fibrillar $\mathrm{A} \beta$ plaques/ deposits, along with the specific $\mathrm{A} \beta$ peptides produced after incubation of $\mathrm{A} \beta 42$ with macrophages or MCM, we examined the possible role of known A $\beta$-degrading enzymes, but especially MMP-9, which has in contrast to neprilysin and insulindegrading enzyme, recently been shown to degrade fibrillar A $\beta 42$ (Yan et al., 2006) and is known to be secreted from various cells including macrophages, astrocytes, and microglia (Gottschall et al., 1995; Muir et al., 2002). Additionally, the expression of MMP-9 has also been observed to be increased in the brain of $\mathrm{AD}$ patients (Backstrom et al., 1992; Lorenzl et al., 2003), indicating that MMP-9 may play an important role in $\mathrm{AD}$ pathology. We observed that cellular MMP-9 expression measured by IHC was indeed apoE isoform-dependent (E2 $>$ E3 $>$ E4) (Fig. $6 F)$. In contrast, MMP-9 activity measured in the media of cultured macrophages was similar regardless of the apoE isoform expressed (Fig. 6F). However, when the three human apoE isoformexpressing macrophages were incubated with $\mathrm{A} \beta$-containing PDAPP brain sections, we observed a marked apoE isoform-dependent difference in MMP-9 activity in the media measured by gelatin zymography (Fig. 6F). There was no difference in MMP-2 activity under these same incubation conditions (Fig. 6F). Both an anti-MMP-9 antibody and MMP-9 inhibitor partially, but substantially, inhibited $\mathrm{A} \beta$ degradation induced
A

B
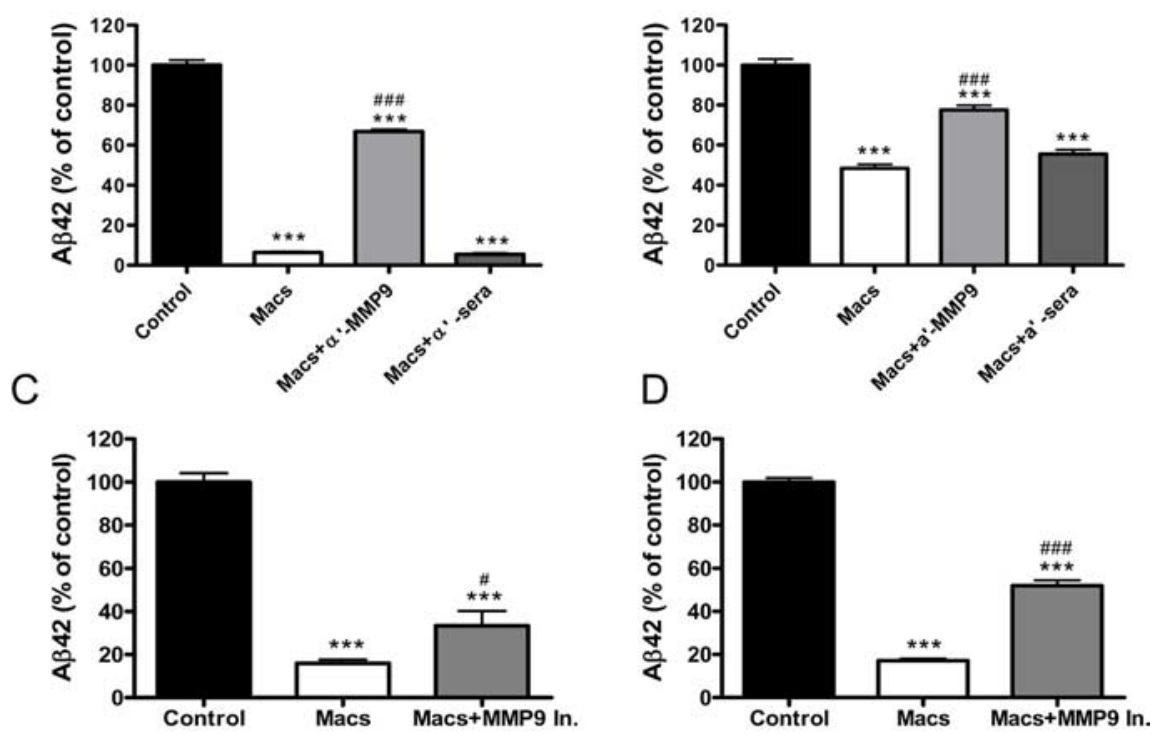

$E$

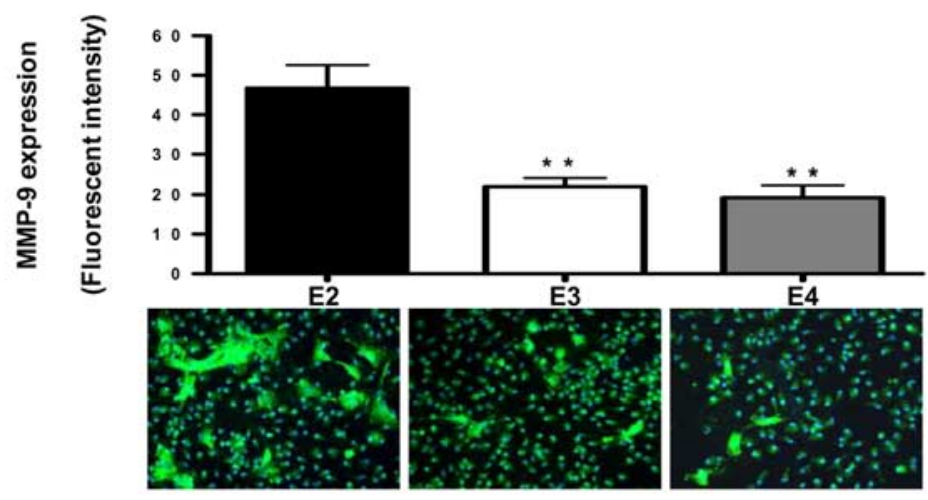

$\mathrm{F}$

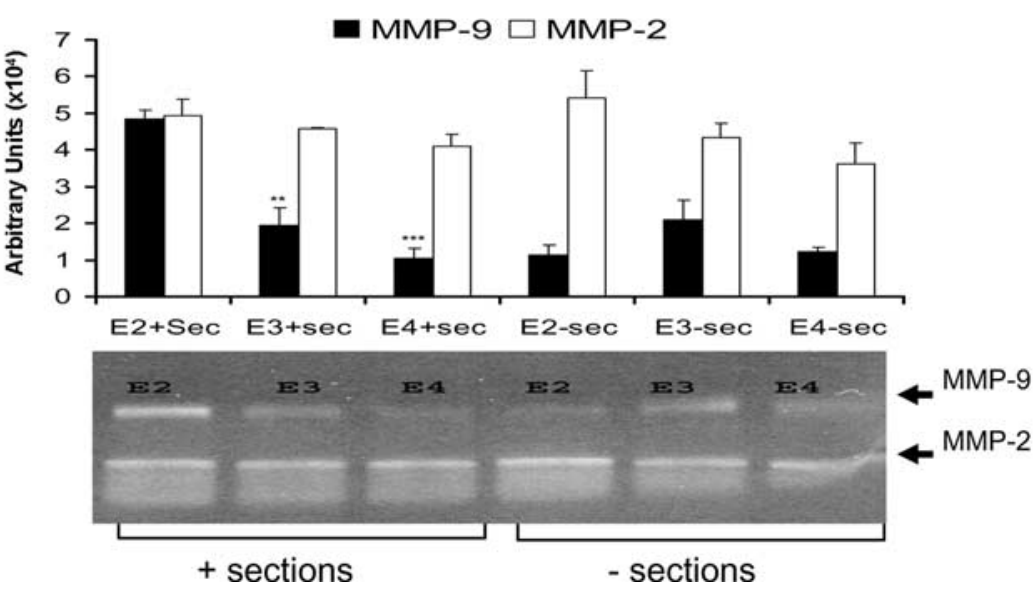

Figure 6. Secretion of MMP-9 is associated with macrophage-dependent $A \beta$ degradation. $A, B, P D A P P$ brain sections were incubated with media alone (Control), macrophages (Macs), macrophages plus a polyclonal rabbit anti-mouse MMP-9 antibody (Macs $+\mathrm{a}^{\prime}$ MMP-9; $50 \mu \mathrm{g} / \mathrm{ml})$, or macrophages plus an anti-rabbit sera (Macs + a'-sera; $50 \mu \mathrm{g} / \mathrm{ml}$ ) for $96 \mathrm{~h}$. C, D, PDAPP brain sections were incubated with media alone (Control), macrophages (Macs), or macrophages plus an MMP-9 inhibitor (Macs + MMP-9 In.; $10 \mu \mathrm{M}$ ) for 96h. $A \beta 42$ levels in the sections $(A, C$ or media $(\boldsymbol{B}, \boldsymbol{D})$ were measured by ELISA and are presented as a percentage of control value. $n=6$ sections per treatment; ${ }^{* * *} p<0.001$ versus Control; ${ }^{*} p<0.05,{ }^{\# \# \#} p<0.001$ versus Macs. Expression of MMP-9 (green) in macrophages isolated from mice expressing human apoE2 (E2), apoE3 (E3), or apoE4 (E4).E, MMP-9 immunoreactive cells were quantified using Image-Pro Plus software. Cell nuclei visualized by DAPI (blue). Original magnification, $20 \times .{ }^{* *} p<0.01$ versus E2. $\boldsymbol{F}$, Gelatin-substrate zymography and quantitative analysis of MMP-9 and MMP-2 activity in media from apoE2 (E2)-, apoE3 (E3)-, or apoE4 (E4)-expressing macrophages incubated with (+ sections) or without ( - sections) PDAPP brain sections. $n=6$ sections per treatment; ${ }^{* *} p<0.01$, ${ }^{* * *} p<0.001$ versus apoE2 macrophages. Representative data from one experiment that was repeated three times with similar results. Error bars represent the SE measurement. 
by macrophages in both PDAPP sections and media. Thus, the apoE isoform-dependent degradation of $\mathrm{A} \beta$ appears to be due, at least in part, to MMP-9; and MMP-9 secretion from macrophages appears to be enhanced in an apoE isoform-dependent manner (Fig. $6 F$ ) after exposure to $\mathrm{A} \beta$. Our finding that $\mathrm{A} \beta$ can induce MMP-9 secretion from macrophages is reminiscent of earlier work by Deb et al. (2003), demonstrating that A $\beta$ stimulates MMP-9 production in astrocytes. Although the exact mechanism(s) underlying the apoE-dependent induction of MMP-9 expression and secretion observed in our experiments is unknown, we have recently found that direct exposure of BV2 cells (a microglia-like cell line) to exogenous apoE increases the expression and secretion of MMP-9 (F. Liu and S. Paul, unpublished observations).

A recent report by Guo et al. (2006) confirms that A $\beta$ exposure stimulates MMP-9 secretion from neonatal astrocytes and further confirms that the addition of exogenous apoE4 attenuates $\mathrm{A} \beta$-induced secretion of MMP-9. There is increasing evidence that MMPs, such as MMP-9, play important roles in regulating extracellular $A \beta$ levels in brain (Yin et al., 2006), and our data demonstrating that apoE isoforms differentially determine the level of MMP-9 secretion from macrophages suggests that the reported effects of various apoE isoforms on amyloid deposition in vivo (Holtzman et al., 1999, 2000; Fagan et al., 2002; DeMattos et al., 2004; Dodart et al., 2005) may be due in part to differences in MMP-9 activity or secretion from apoE-expressing cells, including astrocytes, microglia, or macrophages. However, additional yet to be determined mechanisms may underlie the ability of macrophages to robustly degrade $\mathrm{A} \beta$ either in vitro or in vivo. Further work will be required to elucidate exactly how the three apoE isoforms differentially impact the expression and secretion of MMP-9 and potentially other A $\beta$-degrading enzymes.

Finally, our data further confirm that circulating macrophages are incredibly efficient $\mathrm{A} \beta$-degrading cells and establish an important role for apoE and MMP-9 in mediating A $\beta$ degradation and clearance by macrophages. Given recent data suggesting that bone marrow-derived macrophages and microglia play an important role in $\beta$-amyloid deposition and senile plaque formation in APP transgenic mouse models of AD (Malm et al., 2005; Simard et al., 2006), it is tempting to speculate that macrophage-mediated $\mathrm{A} \beta$ clearance in brain may explain, at least in part, the important role of apoE in determining the genetic risk and pathogenesis of $\mathrm{AD}$.

\section{References}

Backstrom JR, Miller CA, Tökés ZA (1992) Characterization of neutral proteinases from Alzheimer-affected and control brain specimens: identification of calcium-dependent metalloproteinases from the hippocampus. J Neurochem 58:983-992.

Backstrom JR, Lim GP, Cullen MJ, Tökés ZA (1996) Matrix metalloproteinase-9 (MMP-9) is synthesized in neurons of the human hippocampus and is capable of degrading the amyloid- $\beta$ peptide $(1-40)$. J Neurosci 16:7910-7919.

Bales KR, Verina T, Dodel RC, Du Y, Altstiel L, Bender M, Hyslop P, Johnstone EM, Little SP, Cummins DJ, Piccardo P, Ghetti B, Paul SM (1997) Lack of apolipoprotein E dramatically reduces amyloid $\beta$-peptide deposition. Nat Genet 17:263-264.

Bales KR, Verina T, Cummins DJ, Du Y, Dodel RC, Saura J, Fishman CE, DeLong CA, Piccardo P, Petegnief V, Ghetti B, Paul SM (1999) Apolipoprotein $\mathrm{E}$ is essential for amyloid deposition in the APP(V717F) transgenic mouse model of Alzheimer's disease. Proc Natl Acad Sci U S A 96:15233-15238.

Boyles JK, Pitas RE, Wilson E, Mahley RW, Taylor JM (1985) Apolipoprotein $\mathrm{E}$ associated with astrocytic glia of the central nervous system and with nonmyelinating glia of the peripheral nervous system. J Clin Invest 76:1501-1513.
Carson JA, Turner AJ (2002) $\beta$-amyloid catabolism: roles for neprilysin (NEP) and other metallopeptidases? J Neurochem 81:1-8.

Chung H, Brazil MI, Soe TT, Maxfield FR (1999) Uptake, degradation, and release of fibrillar and soluble forms of Alzheimer's amyloid $\beta$-peptide by microglial cells. J Biol Chem 274:32301-32308.

Corder EH, Saunders AM, Risch NJ, Strittmatter WJ, Schmechel DE, Gaskell PC Jr, Rimmler JB, Locke PA, Conneally PM, Schmader KE (1994) Protective effect of apolipoprotein E type 2 allele for late onset Alzheimer disease. Nat Genet 7:180-184.

Davies JQ, Gordon S (2005) Isolation and culture of murine macrophages. Methods Mol Biol 290:91-103.

Deb S, Wenjun Zhang J, Gottschall PE (2003) $\beta$-Amyloid induces the production of active, matrix-degrading proteases in cultured rat astrocytes. Brain Res 970:205-213.

DeMattos RB, Cirrito JR, Parsadanian M, May PC, O’Dell MA, Taylor JW, Harmony JA, Aronow BJ, Bales KR, Paul SM, Holtzman DM (2004) ApoE and clusterin cooperatively suppress $A \beta$ levels and deposition: evidence that ApoE regulates extracellular $A \beta$ metabolism in vivo. Neuron 41:193-202.

Dodart JC, Marr RA, Koistinaho M, Gregersen BM, Malkani S, Verma IM, Paul SM (2005) Gene delivery of human apolipoprotein E alters brain $\mathrm{A} \beta$ burden in a mouse model of Alzheimer's disease. Proc Natl Acad Sci U S A 102:1211-1216.

Eckman EA, Reed DK, Eckman CB (2001) Degradation of the Alzheimer's amyloid $\beta$ peptide by endothelin-converting enzyme. J Biol Chem 276:24540-24548.

Fagan AM, Watson M, Parsadanian M, Bales KR, Paul SM, Holtzman DM (2002) Human and murine ApoE markedly alters A $\beta$ metabolism before and after plaque formation in a mouse model of Alzheimer's disease. Neurobiol Dis 9:305-318.

Games D, Adams D, Alessandrini R, Barbour R, Berthelette P, Blackwell C, Carr T, Clemens J, Donaldson T, Gillespie F, Guido T, Hagopian S, Johnson-Wood K, Khan K, Lee M, Leibowitz P, Lieberburg I, Little S, Masliah E, McConlogueet L, et al. (1995) Alzheimer-type neuropathology in transgenic mice overexpressing V717F $\beta$-amyloid precursor protein. Nature 373:523-527.

Gelfanova V, Higgs RE, Dean RA, Holtzman DM, Farlow MR, Siemers ER, Boodhoo A, Qian YW, He X, Jin Z, Fisher DL, Cox KL, Hale JE (2007) Quantitative analysis of amyloid- $\beta$ peptides in cerebrospinal fluid using immunoprecipitation and MALDI-Tof mass spectrometry. Brief Funct Genomic Proteomic 6:149-158.

Gottschall PE, Yu X, Bing B (1995) Increased production of gelatinase B (matrix metalloproteinase- 9 ) and interleukin- 6 by activated rat microglia in culture. J Neurosci Res 42:335-342.

Guo S, Wang S, Kim WJ, Lee SR, Frosch MP, Bacskai BJ, Greenberg SM, Lo EH (2006) Effects of apoE isoforms on $\beta$-amyloid-induced matrix metalloproteinase-9 in rat astrocytes. Brain Res 1111:222-226.

Holtzman DM, Bales KR, Wu S, Bhat P, Parsadanian M, Fagan AM, Chang LK, Sun Y, Paul SM (1999) Expression of human apolipoprotein E reduces amyloid- $\beta$ deposition in a mouse model of Alzheimer's disease. J Clin Invest 103:R15-R21.

Holtzman DM, Bales KR, Tenkova T, Fagan AM, Parsadanian M, Sartorius LJ, Mackey B, Olney J, McKeel D, Wozniak D, Paul SM (2000) Apolipoprotein $\mathrm{E}$ isoform-dependent amyloid deposition and neuritic degeneration in a mouse model of Alzheimer's disease. Proc Natl Acad Sci U S A 97:2892-2897.

Howell S, Nalbantoglu J, Crine P (1995) Neutral endopeptidase can hydrolyze $\beta$-amyloid(1-40) but shows no effect on $\beta$-amyloid precursor protein metabolism. Peptides 16:647-652.

Johnson-Wood K, Lee M, Motter R, Hu K, Gordon G, Barbour R, Khan K, Gordon M, Tan H, Games D, Lieberburg I, Schenk D, Seubert P, McConlogue L (1997) Amyloid precursor protein processing and A $\beta 42$ deposition in a transgenic mouse model of Alzheimer disease. Proc Natl Acad Sci U S A 94:1550-1555.

Koistinaho M, Lin S, Wu X, Esterman M, Koger D, Hanson J, Higgs R, Liu F, Malkani S, Bales KR, Paul SM (2004) Apolipoprotein E promotes astrocyte colocalization and degradation of deposited amyloid- $\beta$ peptides. Nat Med 10:719-726.

Kurochkin IV (2001) Insulin-degrading enzyme: embarking on amyloid destruction. Trends Biochem Sci 26:421-425.

Leber TM, Balkwill FR (1997) Zymography: a single-step staining method 
for quantitation of proteolytic activity on substrate gels. Anal Biochem 249:24-28.

Lorenzl S, Albers DS, Relkin N, Ngyuen T, Hilgenberg SL, Chirichigno J, Cudkowicz ME, Beal MF (2003) Increased plasma levels of matrix metalloproteinase- 9 in patients with Alzheimer's disease. Neurochem Int 43:191-196.

Majumdar A, Chung H, Dolios G, Wang R, Asamoah N, Lobel P, Maxfield FR (2008) Degradation of fibrillar forms of Alzheimer's amyloid $\beta$-peptide by macrophages. Neurobiol Aging 29:707-715.

Malm TM, Koistinaho M, Pärepalo M, Vatanen T, Ooka A, Karlsson S, Koistinaho J (2005) Bone-marrow-derived cells contribute to the recruitment of microglial cells in response to $\beta$-amyloid deposition in APP/PS1 double transgenic Alzheimer mice. Neurobiol Dis 18:134-142.

Muir EM, Adcock KH, Morgenstern DA, Clayton R, von Stillfried N, Rhodes K, Ellis C, Fawcett JW, Rogers JH (2002) Matrix metalloproteases and their inhibitors are produced by overlapping populations of activated astrocytes. Brain Res Mol Brain Res 100:103-117.

Paresce DM, Ghosh RN, Maxfield FR (1996) Microglial cells internalize aggregates of the Alzheimer's disease amyloid $\beta$-protein via a scavenger receptor. Neuron 17:553-565.

Paresce DM, Chung H, Maxfield FR (1997) Slow degradation of aggregates of the Alzheimer's disease amyloid $\beta$-protein by microglial cells. J Biol Chem 272:29390-29397.

Pihlaja R, Koistinaho J, Malm T, Sikkilä H, Vainio S, Koistinaho M (2008) Transplanted astrocytes internalize deposited $\beta$-amyloid peptides in a transgenic mouse model of Alzheimer's disease. Glia 56:154-163.

Roher AE, Kasunic TC, Woods AS, Cotter RJ, Ball MJ, Fridman R (1994) Proteolysis of A $\beta$ peptide from Alzheimer disease brain by gelatinase A. Biochem Biophys Res Commun 205:1755-1761.

Saunders AM, Strittmatter WJ, Schmechel D, George-Hyslop PH, PericakVance MA, Joo SH, Rosi BL, Gusella JF, Crapper-MacLachlan DR, Alberts MJ, Hulette C, Crain B, Goldgaber D, Roseset AD (1993) Association of apolipoprotein $\mathrm{E}$ allele epsilon 4 with late-onset familial and sporadic Alzheimer's disease. Neurology 43:1467-1472.
Selkoe DJ (2001) Clearing the brain's amyloid cobwebs. Neuron 32:177-180.

Simard AR, Soulet D, Gowing G, Julien JP, Rivest S (2006) Bone marrowderived microglia play a critical role in restricting senile plaque formation in Alzheimer's disease. Neuron 49:489-502.

Sullivan PM, Mezdour H, Aratani Y, Knouff C, Najib J, Reddick RL, Quarfordt SH, Maeda N (1997) Targeted replacement of the mouse apolipoprotein E gene with the common human APOE3 allele enhances diet-induced hypercholesterolemia and atherosclerosis. J Biol Chem 272:17972-17980.

Swanson CJ, Perry KW, Schoepp DD (2004) The mGlu2/3 receptor agonist, LY354740, blocks immobilization-induced increases in noradrenaline and dopamine release in the rat medial prefrontal cortex. J Neurochem 88:194-202.

Takata K, Kitamura Y, Yanagisawa D, Morikawa S, Morita M, Inubushi T, Tsuchiya D, Chishiro S, Saeki M, Taniguchi T, Shimohama S, Tooyama I (2007) Microglial transplantation increases amyloid- $\beta$ clearance in Alzheimer model rats. FEBS Lett 581:475-478.

Wegiel J, Wang KC, Imaki H, Rubenstein R, Wronska A, Osuchowski M, Lipinski WJ, Walker LC, LeVine H (2001) The role of microglial cells and astrocytes in fibrillar plaque evolution in transgenic APP(SW) mice. Neurobiol Aging 22:49-61.

Xu Q, Bernardo A, Walker D, Kanegawa T, Mahley RW, Huang Y (2006) Profile and regulation of apolipoprotein E (ApoE) expression in the CNS in mice with targeting of green fluorescent protein gene to the ApoE locus. J Neurosci 26:4985-4994.

Yan P, Hu X, Song H, Yin K, Bateman RJ, Cirrito JR, Xiao Q, Hsu FF, Turk JW, Xu J, Hsu CY, Holtzman DM, Lee JM (2006) Matrix metalloproteinase- 9 degrades amyloid- $\beta$ fibrils in vitro and compact plaques in situ. J Biol Chem 281:24566-24574.

Yin KJ, Cirrito JR, Yan P, Hu X, Xiao Q, Pan X, Bateman R, Song H, Hsu FF, Turk J, Xu J, Hsu CY, Mills JC, Holtzman DM, Lee JM (2006) Matrix metalloproteinases expressed by astrocytes mediate extracellular amyloid- $\beta$ peptide catabolism. J Neurosci 26:10939-10948. 